\title{
Description of the Last Instar Larva of Phyllocycla gladiata (Hagen in Selys) (Anisoptera: Gomphidae)
}

\author{
Cesar Carriço ${ }^{\bowtie}$, Janira Martins Costa, Tatiana Chrysosotomo Santos \& Danielle Anjos-Santos \\ 1. Museu Nacional/UFRJ, Departamento de Entomologia - Setor de Insetos Aquáticos, e-mail: carrico82@yahoo.fr (Autor para correspondência ${ }^{\varpi}$ ). , \\ jmcosta@globo.com, taticsantos42@yahoo.com.br, daniellesantos2@yahoo.com.br
}

EntomoBrasilis 4(1): 26-29 (2011)

Abstract. The larva of the last instar of Phyllocycla gladiata (Hagen in Selys) is described and illustrated based in only one exuviae, collected at Camorim River, Jacarepaguá, Rio de Janeiro State, Brazil. Exuviae is deposited in the Museu Nacional (UFRJ), Rio de Janeiro, Brazil.

Keywords: Odonata; immatures; sistematics; Brazil

\section{Descrição do Último Ínstar Larvar de Phyllocycla gladiata (Hagen in Selys) (Anisoptera: Gomphidae)}

Resumo. A larva do último ínstar de Phyllocycla gladiata (Hagen in Selys) é descrita e ilustrada com base em uma exúvia coletada no Rio Camorim, Jacarepaguá, Rio de Janeiro, Brasil. A exúvia foi depositada no Museu Nacional (UFRJ), Rio de Janeiro, Brasil.

Palavras-Chave: Odonata; imaturos; sistemática; Brasil

$\mathbf{T}$ he genus Phyllocycla Calvertis composed by 31 species in the New World (Garrison et al. 2006), 18 of these occurs in Brazil (HECKMAN 2006) which only five have been the larvae described: Phyllocycla argentina (Hagen in Selys) (Rodrigues CAPITUlo 1983), Phyllocycla modesta (Belle) (BELle 1970), Phyllocycla ophis (Selys) (Belle 1970), Phyllocycla propinqua (Belle) (BELLE 1972) and Phyllocycla viridipleuris (Calvert) (BELLE 1992). Santos collected three specimens in the last instar, at Rio Camorim, Jacarepaguá, Rio de Janeiro on 18.i.1968, which were reared in laboratory and just one emerged, identified by him as Phyllocycla gladiata (Hagen in Selys) and is described herein.

\section{MATERIAL AND METHODS}

Specimen are deposited in the Departamento de Entomologia, Museu Nacional, Universidade Federal do Rio de Janeiro. The exuviae was preserved in $80 \%$ ethanol and adult was dried and preserved in envelopes. The illustrations were made using camera lucida attached to a stereoscopic microscope; measurements were made using Starrett digital caliper. Terminology for mandibular formula fallows WATSON (1956). S110 refers to abdominal segments $1-10$. The principal characters that differs the known larvae of genus Phyllocycla in the New World are given in Table 1.

\section{RESULTS}

\section{Phyllocycla gladiata (Hagen in Selys)}

Measurements (in mm). Total length $33(\mathrm{n}=1)$; head length 3 , width 3,5 ; antenna length 2 , antenomeres length: I 0,39 ; II 0,22 ; III 1,42; IV 0,23; labium length 4 , width 3 ; thorax length 6,4 ; forewing pads length 6,1 ; hind wing pads length 6,3 ; femur I 2,38, II 2,7, III 4,73; tibia I 3,8, II 4,2; III 3,9; abdomen length 23, width 5,0 .

Description. General shape of body typical of Gomphidae, similar to known larvae of Phyllocycla genus (Figure 1): Integument light brown.

Head (Figure 1). Wider than long, general shape rectangular. Occipital margin slightly concave, eyes large in dorsal view; cephalic lobes rounded, covered with tuft of setae. Antenna small, 4 segmented. Third antennal segment slightly longer than twice the length of the two basal segments combined (Figure 2); fourth antennal segment a tusk-like rudiment, erect and nearly fourth as long as segment 3. Labium light brown, articulation of postmentum and prementum reaching anterior margin of mesocoxa. Prementum smooth (Figure 3), slightly triangular. Ligula convex, with a row of robust, medium truncated scale-like setae, all of the same size. Palpal lobe with end-hook strongly pointed and slightly curved inward and with internal margin smooth; external lateral margin smooth. Movable hook of moderate size, thick, pointed. Mandibles biramous (Figures 4, 5) with following formula (Watson, 1956): L 1234 o a (m 1234)/ R 1234 a(m12)b. Maxillae with seven long incurved hooks on the laciniae (Figure 6); galeae with long setae.

Thorax (Figure 1). Pronotum slightly square. Wing pads parallel reaching base of abdominal S4. Femur I and II short and flattened laterally and thicker than tibiae; hind legs slightly flattened. Tarsal formula 2-2-3.

Abdomen (Figure 1). Elongate, without setae, with small dorsal hook on S3-5 (Figure 7); segment 10 long (7 mm). Lateral spines on S8 and 9, these spines small and sub-equal. Anal appendages short. 


\section{DISCUSSION}

Based on shape of ligula and similarity of larvae we belive that $P$. gladiata shows closer affinities to $P$. viridipleuris, but differs by characters following: 1 ) total length in $P$. gladiata 33 (in $P$. viridipleuris $35-37$ ); 2) antennae with long hairs in $P$. gladiata (short in $P$. viridipleuris); 3).abdominal dorsal hook in P. gladiata on segments 3-5 (in P. viridipleuris 3-7); 4) abdominal lateral spines in P. gladiata on segments 8-9 (in $P$. viridipleuris 7-9).

The adult males of $P$. gladiata differ of $P$. viridipleuris by characters following: 1) superior anal appendage with a superior tooth at one-fourth of its length in P. gladiata (tooth absent in $P$. viridipleuris); 2) the widest point of the lateral dilatation on the eighth abdominal segment is at the mid-length in $P$. gladiata (at the distal-length in P. viridipleuris); 3 ) anal appendage in $P$. gladiata robust (delicate and incurved to down in $P$. viridipleuris).

\section{ACKNOWLEDGEMENTS}

We are grateful to L. A. A. Costa for the drawings that illustrate this manuscript and Dra. Neusa Hamada from INPA for help us with manuscript. This paper was supported in part by Coordenação de Aperfeiçoamento de Pessoal de Nível Superior (CAPES), Conselho Nacional de Desenvolvimento Científico e Tecnológico (CNPq) and Fundação Carlos Chagas Filho de Amparo à Pesquisa do Estado do Rio de Janeiro (FAPERJ).

\section{REFERENCES}

Belle, J., 1970. Studies on South American Gomphidae (Odonata) with special reference to the species from Surinam. Studies on the Fauna of Suriname, 11(43): 1-158.
Belle, J., 1972. Further studies on South American Gomphidae (Odonata). Tijdschrift voor Entomologie, 115(5): 217-240.

Belle, J., 1992. Studies on ultimate instar larvae of Neotropical Gomphidae, with the description of Tibiogomphus gen. nov. (Anisoptera). Odonatologica, 21(1): 1-24.

Fleck, G., 2002. Contribution à la connaissance des Odonates de Guyane française: notes sur les genres Epigomphus Hagen, 1854, et Phyllocycla Calvert, 1948 (Anisoptera, Gomphidae). Bulletin de la Société Entomologique de France, 107(5): 493501.

Garrison, R.W., N.von Ellenrieder, \& J.A. Louton, 2006. Dragonfly genera of the New World: An illustrated and annotated key to the Anisoptera. The Johns Hopkins University Press, Baltimore, 1-359p.

Heckman, C.W., 2006. Encyclopedia of South American Aquatic Insects: Odonata-Anisoptera. Illustrated Keys to Known Families, Genera and Species in South America. Springer, viii+ 725p.

Needham, J.G., 1940. Studies on Neotropical Gomphine dragonflies (Odonata). Transactions of the American Entomological Society, 65: 363-394.

Rodrigues Capitulo, A., 1983. La ninfa de Phyllocycla argentina (Hagen in Selys) 1878 (Odonata, Gomphidae). Revista de la Sociedad Entomológica Argentina, 42(1-4): 267-271.

Watson, M.C., 1956. The utilization of mandibular armature in taxonomic studies of anisopterous nymphs. Transaction of the American Entomological Society, Philadelphia, 81: 155209.

Recebido em: 30/06/2010 Aceito em: 19/08/2010

$* * * * * * * * * * * * *$
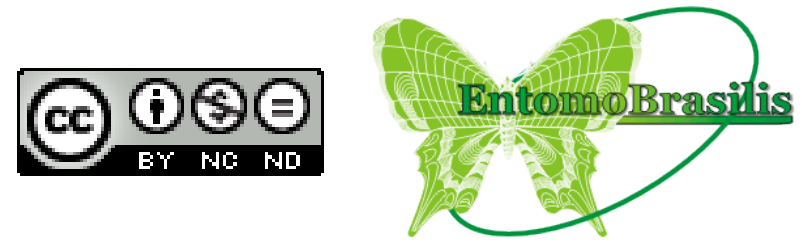

C. Carrico, J.M. Costa, T.C. Santos \& D. Anjos-Santos, 2011. Description of the Last Instar Larva of Phyllocycla gladiata (Hagen in Selys) (Anisoptera: Gomphidae). EntomoBrasilis, 4(1): 26-29. www.periodico.ebras.bio.br/ojs
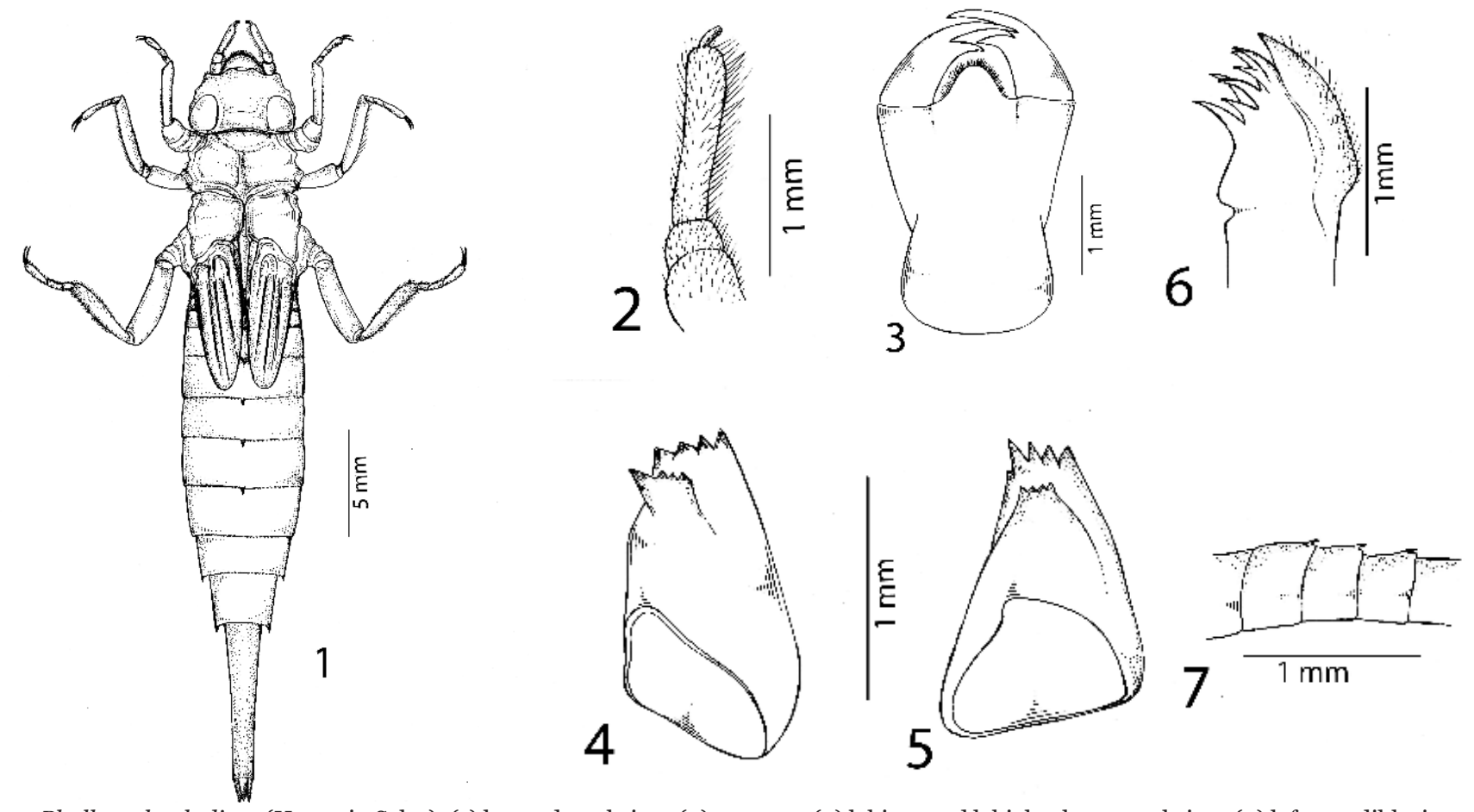

Figures 1-7: Phyllocycla gladiata (Hagen in Selys): (1) larva, dorsal view. (2) antenna. (3) labium and labial palp, ventral view. (4) left mandible, inner view. (5) right mandible, inner view. (6) maxillae, dorsal view. (7) abdominal segments $3-5$, lateral view. 


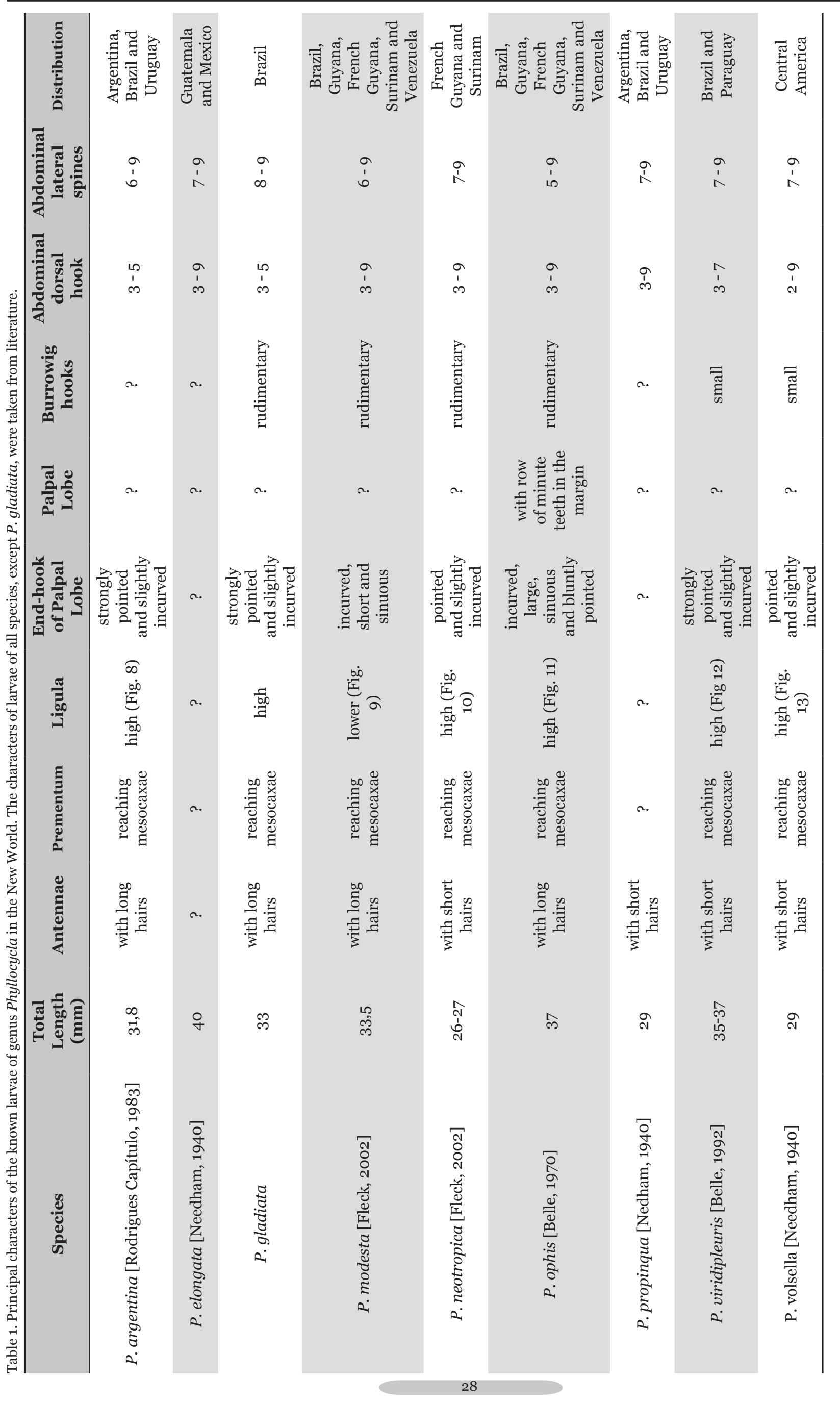



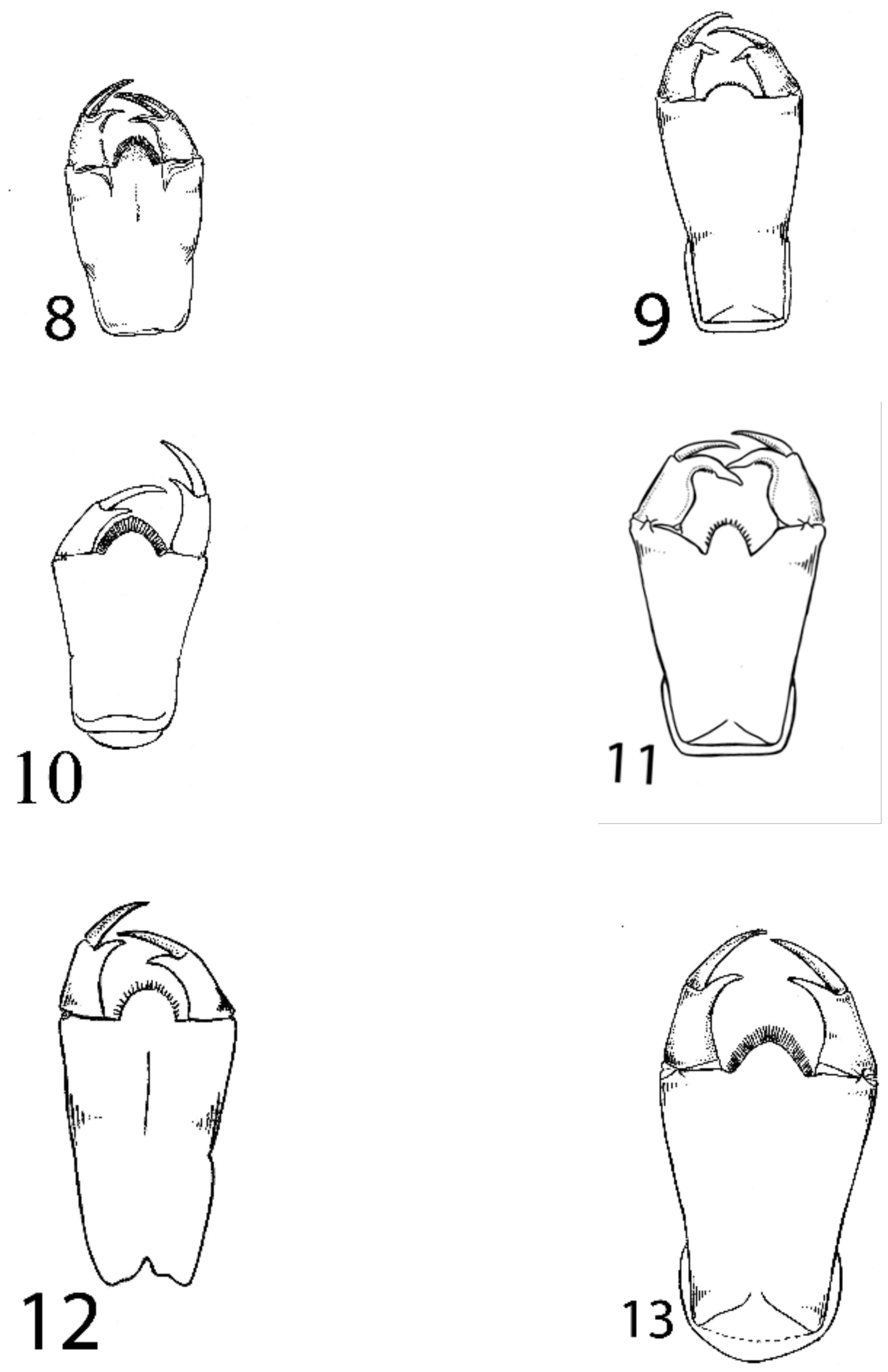

Figures 8-13: Phyllocycla argentina: (8) labium and labial palp, ventral view (after Rodrigues CAPítulo 1983). Phyllocycla modesta: (9) labium and labial palp, ventral view (after FLECK 2002). Phyllocycla neotropica: (10) labium and labial palp, ventral view (after FLECK 2002). Phyllocycla ophis: (11) labium and labial palp, ventral view (after BELLE 1970). Phyllocycla volsella: (12) labium and labial palp, ventral view (after NEEDHAM 1940). Phyllocycla viridipleuris: (13) labium and labial palp, ventral view (after BeLLE 1992). 